\title{
PROTECTIVE ROLE OF CRATAEGUS MONOGYNA ON SPERM QUALITY AND TESTIS OXIDATIVE STRESS AGAINST COPPER- INDUCED TOXICITY
}

\author{
CRATAEGUS MONOGYNA 'NIN, BAKIR KAYNAKLI TOKSISITEYE KARŞI SPERM \\ KALITESİ VE TESTIS OKSIDATIFF STRESI ÜZERINDEKİ KORUYUCU ROLÜ
}

\author{
Feriel REMITA $^{1, *}$, Cherif ABDENNOUR ${ }^{1}$, Amina TALBI ${ }^{1}$, Kamel KHELILI ${ }^{1}$ \\ ${ }^{1}$ Laboratory of Animal Ecophysiology, Department of Biology, Faculty of Sciences, University \\ Badji Mokhtar-Annaba, Annaba 23000, Algeria
}

\begin{abstract}
Objective: The purpose of this study was to investigate the possible beneficial use of common hawthorn Crataegus monogyna aqueous extract at $1.5 \mathrm{~g} / \mathrm{Kg}$ bw/day against chronic copper sulfate intoxication $(100 \mathrm{mg} / \mathrm{Kg} \mathrm{bw})$ in Wistar rats.

Material and Method: Animals were divided into 6 groups; the untreated control $(C), 2$ positive controls treated respectively with hawthorn fruits $(F)$ and leaves $(L), 1$ group treated with copper $(C u)$ and 2 combined treatment groups treated with $\mathrm{Cu}$ and hawthorn-fruits $(\mathrm{CuF})$ and $\mathrm{Cu}$ and hawthorn-leaves $(\mathrm{CuL})$. After 30 days of oral administration, testis weight and plasma testosterone levels were evaluated, in addition to the epididymal sperm concentration, motility, vitality, velocity (VCL, VSL and VAP), the amplitude of lateral head displacement (ALH), and the beat cross frequency (BCF). Testicular glutathione (GSH), malondialdehyde (MDA), and glutathione peroxidase (GPx) were also evaluated.

Result and Discussion: Cu exposure reduced testosterone, sperm concentration, live sperm, VCL, VSL, $V A P, A L H, B C F, G S H$, and GPx levels compared to control groups. Dead sperm and MDA levels were increased in rats of $\mathrm{Cu}$ group compared to the untreated control. When compared to the Cu group, levels of testosterone, sperm concentration, sperm motility, live sperm, VCL, VSL, VAP, ALH, BCF, GSH, and GPX were much higher in the $C u F$ and $C u L$ groups, along with a significantly lower MDA concentration. In conclusion, hawthorn, when co-administered as an aqueous extract with $\mathrm{Cu}$, protected most biological markers against copper toxicit, while positive control $(s)$ boosted sperm concentration and velocity (VCL and $V A P)$.

Keywords: C. monogyna, CASA, Copper, sperm, testosterone
\end{abstract}

\footnotetext{
* Corresponding Author/Sorumlu Yazar: Feriel Remita

e-mail / e-posta: remitaferiel@gmail.com
} 


\section{$\ddot{O Z Z}$}

Amaç: Bu çalışmanın amacı, Wistar sıçanlarında, kronik bakır sülfat zehirlenmesine (100mg / Kg bw) karşı yaygın alıç Crataegus monogyna sulu ekstraktının (1.5g / Kg bw/ gün) olası faydalı kullanımını araştırmaktır.

Gereç ve Yöntem: Hayvanlar, tedavi edilmemiş kontrol $(C)$, sırasıyla alıç meyveleri $(F)$ ve yaprakları $(L)$ ile muamele edilmiş 2 pozitif kontrol, bakır (Cu) ile muamele edilmiş grup ve $\mathrm{Cu}$ ve alıç meyveleri $(\mathrm{CuF})$ ve $C u$ ve alıç yaprakları (CuL) ile muamele edilmiş 2 kombine tedavi grubu olmak üzere 6 gruba ayrlmiştır. 30 günlük oral uygulamadan sonra, epididimal sperm konsantrasyonu, motilite, canlılık, hiz (VCL, VSL ve $V A P)$, diş yana baş deplasmanının amplitüdü (ALH) ve sperm kuyruğu vuruş sıklığının (BCF) yanısıra testis

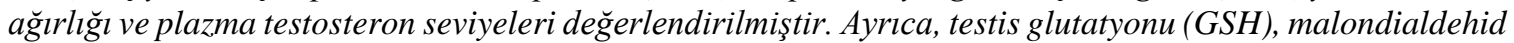
(MDA) ve glutatyonperoksidaz (GPx) da değerlendirilmiştir.

Sonuç ve Tartışma: $C u$ maruziyeti, kontrol gruplarına kıyasla testosteron, sperm konsantrasyonu, canlı sperm, VCL, VSL, VAP, ALH, BCF, GSH ve GPx seviyelerini azaltmıştır. Cu grubunun sıçanlarında ölü sperm ve MDA seviyeleri, tedavi edilmeyen kontrole kıyasla artmıştır. Cu grubuyla karşılaştırıldiğında, testosteron seviyeleri, sperm konsantrasyonu, sperm motilitesi, canli sperm, VCL, VSL, VAP, ALH, BCF, $G S H$ ve GPx seviyeleri $C u F$ ve CuL gruplarında çok daha yüksek ve MDA konsantrasyonlart ise anlaml olarak düşüktür. Sonuç olarak, alıç, Cu ile sulu bir özüt olarak uygulandı̆̆ında, bakır toksisitesine karşı çoğu biyolojik belirteci korumuş ve sperm konsantrasyonunu ve hızını (VCL ve VAP) artırmıştır.

Anahtar Kelimeler: Bakır, C. monogyna, CASA, sperm, testosteron

\section{INTRODUCTION}

Copper is a trace element and important component of numerous metalloenzymes that are involved in energy and antioxidant metabolisms. However, some of copper's chemical forms, such as copper sulfate are very toxic [1]. Copper binds to binding proteins in the bloodstream and, distributes to all tissues especially the brain and the liver, which can secrete the excess of the metal into bile. Hypercupremia may cause several oxidation reactions, inflammations, and tissues damage by inducing free radical generations [2]. Copper can enter the body orally through food, by inhalation into the lungs or through the skin by direct contact. Copper is used in agriculture as a fungicide, herbicide, and insecticide [3]. Also, it is used as an electrical conductor in several industries, it has many chemical applications, and is known as a coinage metal. In nature, copper exposure may be caused by clouds of dust, volcanoes and forest fires. Copper dyshomeostasis has been linked to a variety of disorders. For example, ATP7A and ATP7B are both involved in copper metabolism; mutations of the former lead to Menkes' disease, but that of the latter causes Wilson's disease [4].

Previous studies showed that human spermatogenesis has decreased by up to $60 \%$ after 40 years [5]. In addition, many couples today are infertile [6]; this male sexual disorder may be related to pollutants [7]. The discharge of heavy metals into the environment has led to a harmful deterioration of the ecosystems [8]. Copper can cause several problems both in excess and deficiency. Copper imbalance in both men and women might affect reproduction, and women are said to be copper-dominant and men are zinc-dominant [1]. Excess copper harms male reproduction; metal 
contamination provokes certain pathophysiological alterations in humans and animals, affecting sperm quality and causing infertility [9]. In its ionic form, copper is toxic to a variety of cells, including human spermatozoa [10]. According to Wong et al. [11], a positive correlation between blood $\mathrm{Cu}$ concentration and sperm motility dysfunction was found. However, cytosolic $\mathrm{Cu}$ is mainly bound to metallothioneins that may reduce its toxicity to some extent. The hydroxyl free radicals induced by the Fenton reaction of copper are very destructive to tissues [12] of the testis and epididymis, and also reduce antioxidant biomarkers such as catalase, superoxide dismutase, glutathione, and glutathione peroxidase. This oxidation can change sperm quality by modifying spermatozoa shape and movement. In addition, copper's effect on the pituitary receptor can provoke hormonal imbalance. Copper exposure causes several symptoms such as erectile dysfunction, anxiety, and testicular pain [1]. Furthermore, high copper levels can lead to a decrease in sperm concentration, motility, and vitality [13].

Today, numerous plants are used as remedies in the treatment of many ailments [14]. Hawthorn Crataegus monogyna is a very common shrub plant in the Mediterranean basin that is used by the local population in North Africa in certain traditional therapeutic applications including for hypertension, heart disorders, diabetes, anxiety, cancer, and some abdominal symptoms. The Crataegus spp have been used in medicinal treatments and as food [15]. Many studies conducted in Europe, Asia, and the USA showed that hawthorn has a high content of phenolic compounds that show antioxidant activity by scavenging superoxide anions, hydroxyl radicals, hydrogen peroxides, and by reducing lipid peroxidation [16].

This study aims to investigate the possible protective role of common hawthorn Crataegus monogyna aqueous extract against the induced toxicity of copper sulfate in Wistar rats by measuring certain reproductive and oxidative stress markers.

\section{MATERIAL AND METHOD}

\section{Plant preparation}

Fruits and leaves of the common hawthorn Crataegus monogyna were harvested every 3 days from the region of Annaba in the northeast of Algeria in November. Each of the 2 aqueous extracts of fruits $(\mathrm{F})$ and leaves $(\mathrm{L})$ was prepared daily by crushing $1.5 \mathrm{~g} / \mathrm{kg}$ bw (fruits and leaves) in an appropriate volume of distilled water and letting the mixtures streep overnight (12 hours) at room temperature in order to obtain $10 \mathrm{ml}$ of filtered solutions of each of fruits and leaves in the morning. The aqueous extracts were administrated to rats per os daily for a period of 30 consecutive days. 


\section{Preparation of copper solution}

Copper sulfate powder $(\mathrm{Cu})$ was freshly dissolved in distilled water; this solution was administered to animals by gavage at a dose of $100 \mathrm{mg} / \mathrm{kg}$ bw/day for 30 days.

\section{Experimental design}

Wistar rats were purchased from the Pasteur Institute (Algiers), each weighing 196 $\pm 8 \mathrm{~g}$. Thirty-six males were divided into 6 equal groups: the control $(\mathrm{C})$, the copper group $(\mathrm{Cu})$ which received $100 \mathrm{mg} / \mathrm{kg}$ bw/day, the fruits group $(\mathrm{F})$ which received an aqueous extract of $1.5 \mathrm{~g}$ fruits $/ \mathrm{kg}$ bw/day, the leaves group (L) which recieved an aqueous extract of $1.5 \mathrm{~g}$ leaves/kg bw/day, and 2 other groups that were treated with a combination of copper and fruits $(\mathrm{CuF})$ or copper and leaves $(\mathrm{CuL})$. Rats received tap water and standard diet ad libitum. After 30 days of continuous treatment, animals were sacrificed by decapitation; the blood was collected in heparinized tubes and then centrifuged at $3000 \mathrm{rpm}$ for $10 \mathrm{~min}$. The plasma obtained was stored at $-20^{\circ} \mathrm{C}$ along with the testes, which had already been weighed, till further analysis. Animals' treatments were authorized by the Ethical Committee of Animal Sciences at the University of Badji Mokhtar-Annaba, before starting the experimental work.

\section{Measurement of testosterone}

The Ultrasensitive TESTOSTERONE ELISA test (DRG instrument GnbH) is based on the principle of a solid phase enzyme-linked immunosorbent assay. The assay system utilizes a unique monoclonal antibody directed against a district antigenic determinant on the intact testosterone molecule. Mouse monoclonal anti-testosterone antibody was used for solid phase (microtiter wells) immobilization, and goat anti-testosterone antibody was used in the antibody-enzyme (horseradish peroxidase) conjugate solution. The test sample was allowed to react simultaneously with the antibodies. After 2 hours of incubation at room temperature with shaking, the solid phase and enzyme were washed with distilled water to remove unbound labeled antibodies. A solution of tetramethylbenzidine (TMB) was added and incubated for 20 minutes, resulting in the development of a blue color. The color development was stopped with the addition of $1 \mathrm{~N} \mathrm{HCl}$, and the resulting yellow color was measured using a spectrophotometer at $450 \mathrm{~nm}$. The concentration of testosterone was directly proportional to the color intensity of the sample.

\section{Semen analysis}

Semen analysis was realized using the Computer-Assisted Sperm Analysis Method (CASA) using Sperm Class Analysis (SCA ${ }^{\circledR}$, Microptic, Barcelona, Spain). The epididymal semen was 
obtained immediately after sacrifice, and then a drop of semen (about $1 \mu \mathrm{l}$ ) was diluted with a physiological solution of $\mathrm{NaCl} 0.09 \%$, and $5 \mu \mathrm{L}$ of the mixture was placed in an empty chamber slide (GoldCyto model). The slide was then placed on a Nikon Eclipse (Nikon E200-LED) microscope at the phase objective (x4). The sperm markers of concentration, motility, vitality linearity (VCL, VSL), velocity (VAP), the amplitude of lateral head displacement (ALH) and the beat cross frequency (BCF) were automatically calculated.

\section{Hypo-osmotic swelling (HOS) test}

The HOST test was used to evaluate the integrity of sperm by exposing a drop of sperm, derived from the epididymis cauda, to the hypo-osmotic solution composed of fructose and sodium citrate [17], after which 100 spermatozoa were observed and the number of live sperms (as shown by an inflation of the tail) were counted.

\section{Measurement of oxidative stress parameters}

Frozen stored samples of testis were thawed and 100mg of each sample was taken and transferred to test tubes for the determination of glutathione (GSH) using the method of Cory and Weckbecker [18]. The testicular total proteins were quantified according to the colorimetric method of Bradford [19] by using the Coomassie Brilliant Blue G-250. Malondialdehyde (MDA) was estimated by using the method of Ohkawa et al. [20]. The measurement of glutathione peroxidase (GPx) was realized by the method of Flohe and Günzler [21].

The dosage of glutathione (GSH) was carried out according to the method of Wekbeker and Cory (1988). The principle of this assay is based on the measurement of the optical absorbance of the acid 2-nitro-5-mercapturic. The latter results from the reduction of 5,5'-dithio-bis-2- acid nitrobenzoïque (Ellman's reagent, DTNB) by groups (-SH) of glutathione. For this deproteinization of the homogenate is essential in order to keep only specific thiol groups of glutathione.

The tissues proteins were quantified according to the colorimetric method of Bradford (1967) who uses Gloss Blue Coomassie G250 (BBC) as a reagent and the serum albumin of breef (BSA) as standard. The $\mathrm{BBC}$ reacts with the amino groups (-NH2) for protein to form a complex of blue color. The emergence of this color reflects the degree of ionization of the acid and intensity established the concentration of protein which is measured spectrophotometrically at $595 \mathrm{~nm}$.

MDA is a product of lipid peroxidation reactions that forms during the attack of polyunsaturated lipids by reactive oxygen species generated by certain contaminants. In our study, testicular MDA levels were assessed using the method of Ohkawa et al (1979). The dosage is based on the formation in an acidic and hot environment $\left(100^{\circ} \mathrm{C}\right)$ between MDA and thiobarbituric acid 
(TBA) of a colored pigment absorbing at $530 \mathrm{~nm}$, extractable by organic solvents like butanol.

The enzymatic activity of glutathione peroxidase (GPx) was measured by the method of Flohe and Gunzler (1984). This method is based on the reduction of hydrogen peroxide (H 2O2) in the presence of reduced glutathione (GSH), the latter is transformed into (GSSG) under the influence of the GPx.

\section{Statistical analysis}

Statistics was realized using (MINITAB 18 Software ANOVA Tukey). Results are expressed as mean \pm standard deviation. The significant test was considered at $\mathrm{p}<0.05$.

\section{RESULT AND DISCUSSION}

\section{Testicular weights and testosterone}

Results presented in Table 1 showed that differences between the absolute testicular weights of all groups were statistically non-significant when compared to the control. Testosterone concentration (Table 1) was significantly lower in $\mathrm{Cu}$ group compared to the untreated control. When compared to the $\mathrm{Cu}$ group, testosterone was significantly higher in the $\mathrm{CuF}$ and $\mathrm{CuL}$ groups. Testosterone levels of the positive control $\mathrm{F}$ and $\mathrm{L}$ groups were significantly lower compared to the control.

Table 1. Mean testicular absolute weights $(\mathrm{g})$, and testosterone level $(\mathrm{ng} / \mathrm{ml})$ in wistar rats treated with copper sulphate and C. monogyna leaves and fruits extracts for one month. Results are expressed as mean $\pm \mathrm{SD}$.

\begin{tabular}{lcc} 
Groups & Testis $(\mathbf{g})$ & Testosterone $(\mathbf{n g} / \mathbf{m l})$ \\
\hline Control & $1.67 \pm 0.31^{\mathrm{a}}$ & $5.80 \pm 0.007^{\mathrm{a}}$ \\
$\mathbf{C u}$ & $1.67 \pm 0.015^{\mathrm{a}}$ & $1.32 \pm 0.150^{\mathrm{f}}$ \\
$\mathbf{F}$ & $1.67 \pm 0.01^{\mathrm{a}}$ & $5.55 \pm 0.121^{\mathrm{b}}$ \\
$\mathbf{L}$ & $1.69 \pm 0.02^{\mathrm{a}}$ & $5.23 \pm 0.012^{\mathrm{c}}$ \\
$\mathbf{C u F}$ & $1.67 \pm 0.012^{\mathrm{a}}$ & $3.10 \pm 0.008^{\mathrm{e}}$ \\
$\mathbf{C u L}$ & $1.67 \pm 0.01^{\mathrm{a}}$ & $4.10 \pm 0.003^{\mathrm{d}}$ \\
\hline Means that do not share the same letter are significantly different at $\mathrm{p}<0.05$.
\end{tabular}

\section{Sperm concentration}

Results of semen analysis indicated a significant lower sperm concentration in the $\mathrm{Cu}$ group compared to the control, Sperm concentration showed no significant difference between the F group and the control but was significantly higher in the L groupthan in the control, and significantlyhigher in the $\mathrm{CuF}$ and $\mathrm{CuL}$ groups compared to the $\mathrm{Cu}$ group (Figure 1). 


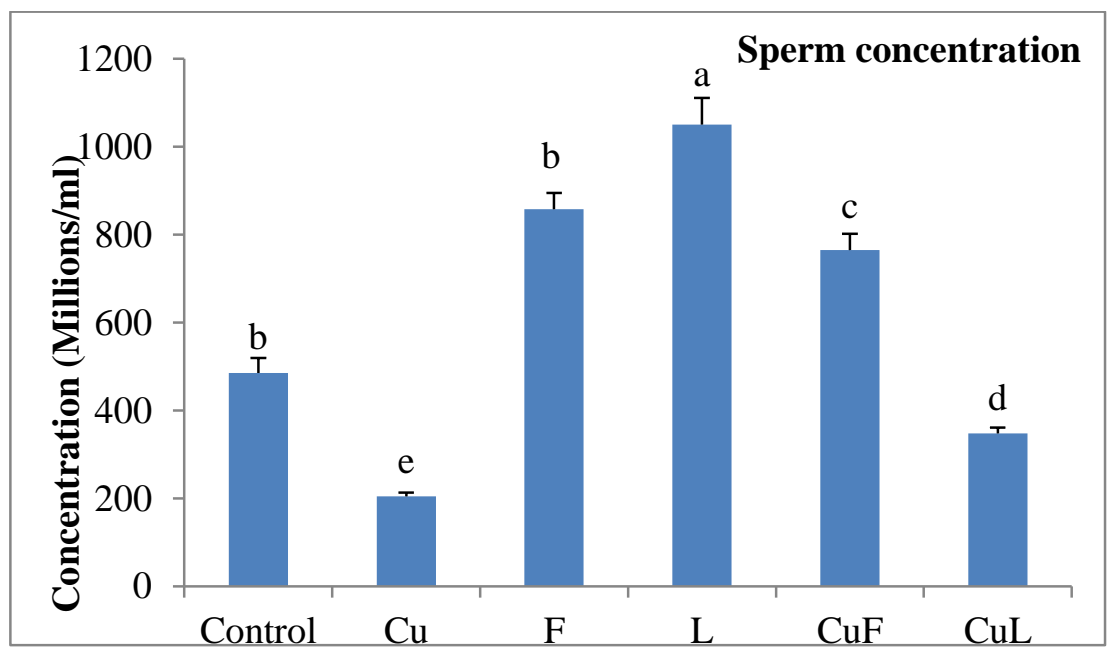

Figure 1. Evaluation of sperm concentration (Millions $/ \mathrm{ml}$ ) of Wistar rats exposed to copper sulphate and $C$. monogyna leaves and fruits for one month. Results are expressed as mean $\pm \mathrm{SD}$. Means that do not share the same letter are significantly different at $p<0.05$.

\section{Sperm motility}

Sperm motility was significantly lower in both the $\mathrm{Cu}$ group and the $\mathrm{F}$ group compared to the untreated control. Motility was also significantly lower in the $\mathrm{CuF}$ and $\mathrm{CuL}$ groups compared to the control but higher than the $\mathrm{Cu}$ group (Figure 2).

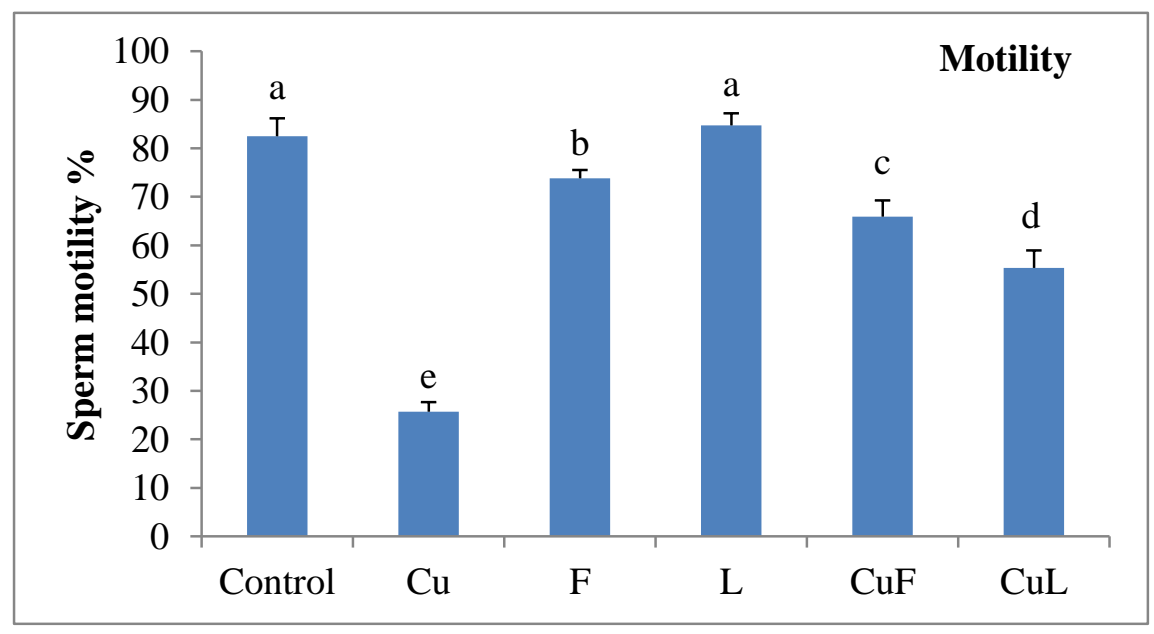

Figure 2. Evaluation ofsperm motility percentage (\%) of Wistar rats treated with copper sulphate and C. monogyna leaves and fruits for one month. Results are expressed as mean \pm SD.Means that do not share the same letter are significantly different at $\mathrm{p}<0.05$. 


\section{Dead and live sperm}

Percentage of dead sperm in the $\mathrm{Cu}$ group was significantly higher compared to the control, while $\mathrm{F}, \mathrm{L}, \mathrm{CuF}$, and $\mathrm{CuL}$ group showed levels close to that of the control (Figure 3). On the other hand, percentage of dead sperm was remarkably lower in the combined treatments of $\mathrm{CuF}$ and $\mathrm{CuL}$ groups compared to the $\mathrm{Cu}$ exposed group. Live sperm of the $\mathrm{Cu}$ group was slightly decreased when compared to the control, with a weak reduction in the $\mathrm{CuF}$ and $\mathrm{CuL}$ groups, whereas $\mathrm{F}, \mathrm{CuF}$ and $\mathrm{CuL}$ have kept in close percentage as that of the control (Figure 3).

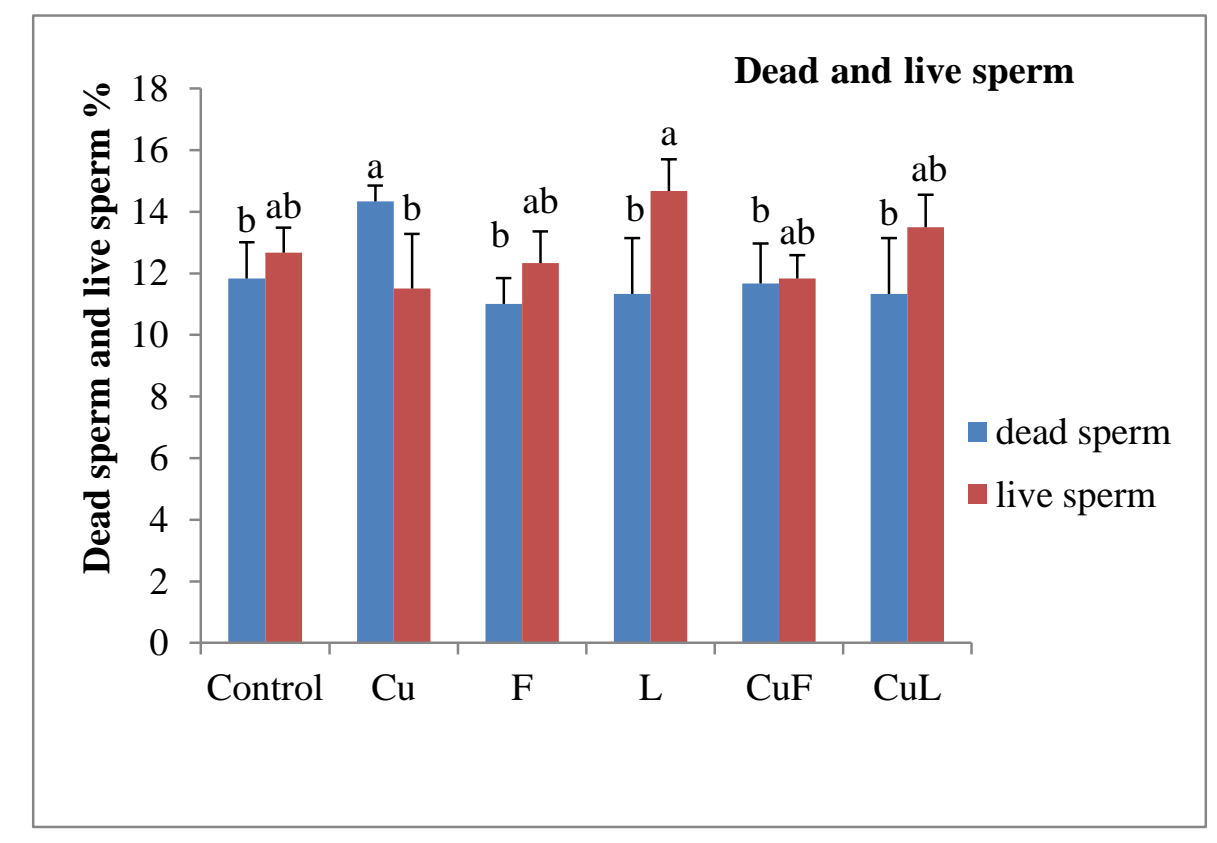

Figure 3. Evaluation of sperm vitality (dead sperm and live sperm percentage \%) of Wistar rats exposed to copper sulphate and C. monogyna leaves and fruits for one month. Results are expressed as mean \pm SD. Means that do not share the same letter are significantly different at $p<0.05$.

\section{Sperm velocity}

The VCL, VSL, and VAP of spermfrom the Cu group were significantly lower compared to the control. VCL, VSL, and VAP of spermin the $\mathrm{CuF}$ and $\mathrm{CuL}$ groups were significantly higher than the $\mathrm{Cu}$ group, and not statistically different fromthe control group (Figure 4). The VCL and the VAP of theL positive control were significantly higher than that of the control group. 


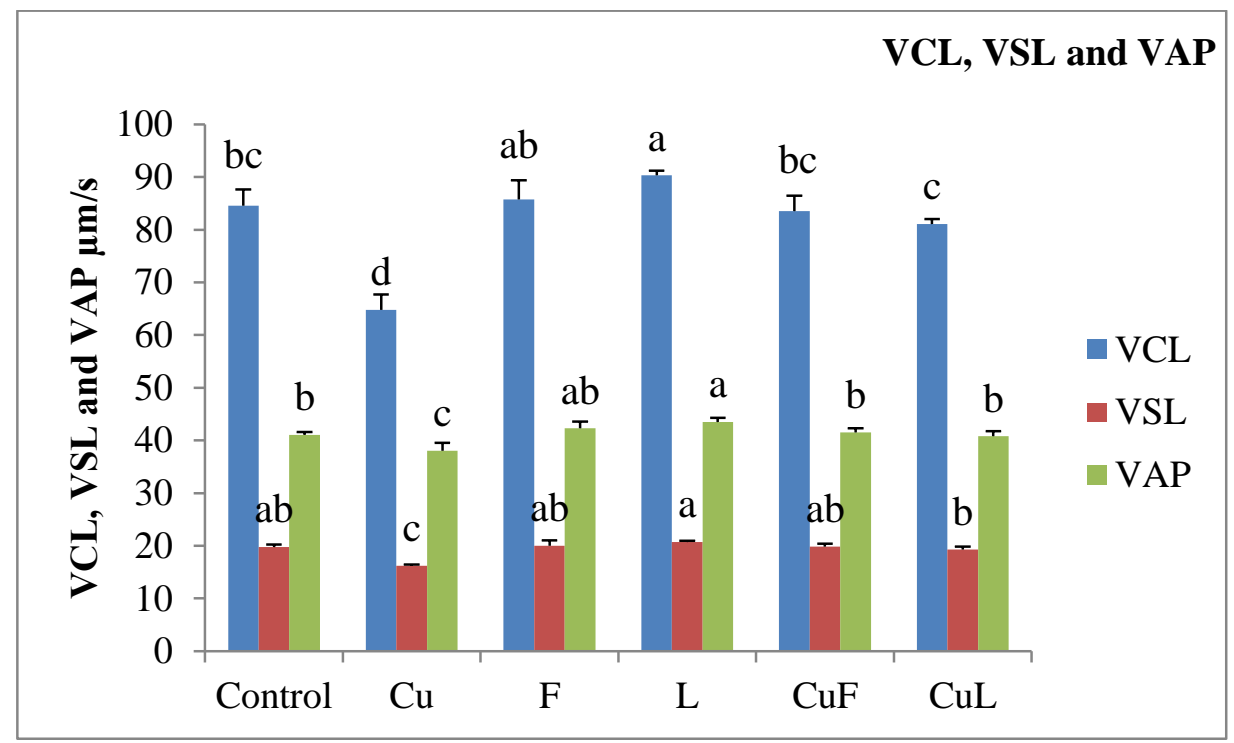

Figure 4. Evaluation of sperm velocity (VCL, VSL and VAP) of Wistar rats exposed to copper sulphate and C. monogyna leaves and fruits for one month. Results are expressed as mean \pm SD. Means that do not share the same letter are significantly different at $p<0.05$.

\section{Amplitude of lateral head displacement}

The sperm ALH was significantly lower in the $\mathrm{Cu}$ group compared to the control (Figure 5). Sperm ALH in the other groups were not significantly different from that of the control.

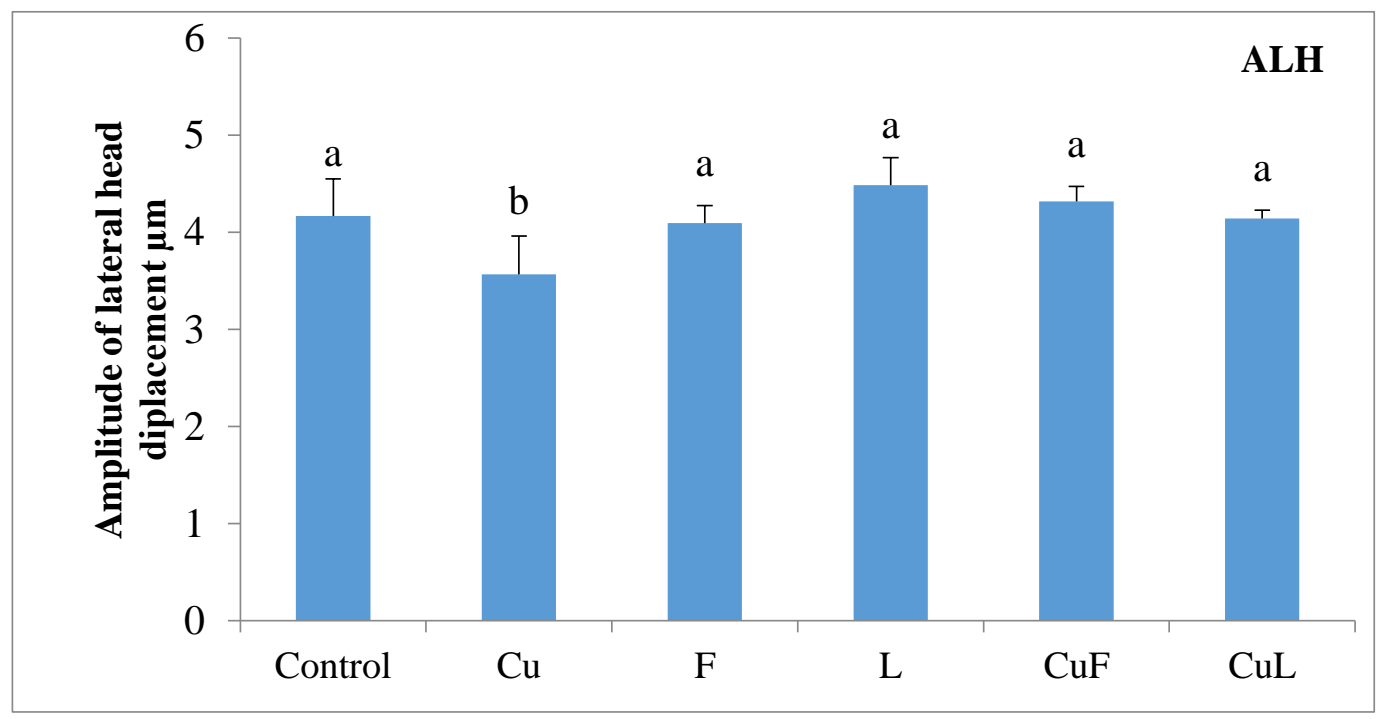

Figure 5. Evaluation of sperm amplitude lateral head displacement (ALH) of Wistar rats exposed to copper sulphate and C. monogyna leaves and fruits for one month. Results are expressed as mean \pm SD. Means that do not share the same letter are significantly different at $p<0.05$. 


\section{Beat cross frequency}

The $\mathrm{BCF}$ was lower in the $\mathrm{Cu}$ group compared to the control, while $\mathrm{F}, \mathrm{L}, \mathrm{CuF}$ and $\mathrm{CuL}$ groups did not differ significantly from the control (Figure 6).

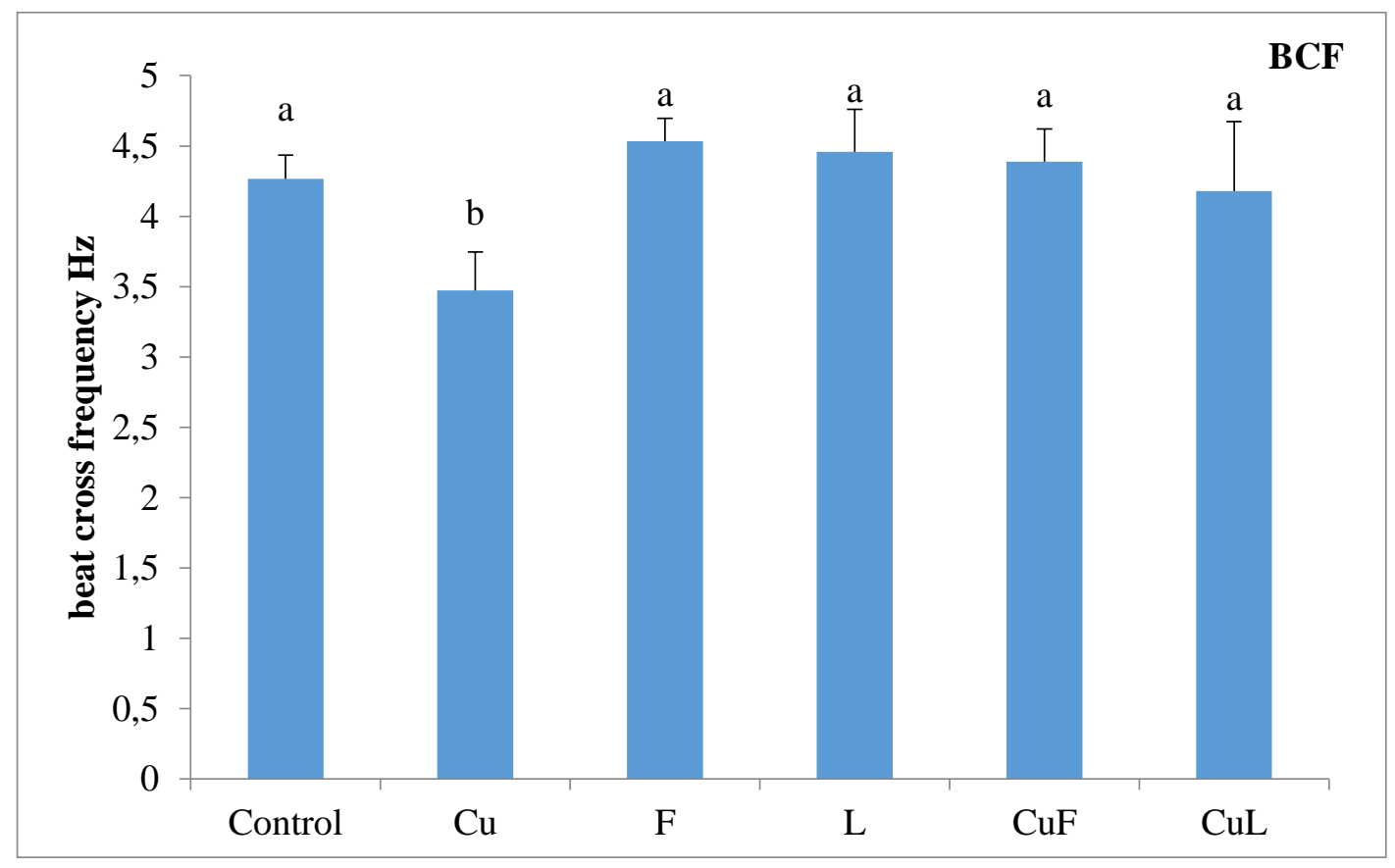

Figure 6. Evaluation of sperm beat cross frequency (BCF) of Wistar rats exposed to copper sulphate and C. monogyna leaves and fruits for one month. Results are expressed as mean \pm SD. Means that do not share the same letter are significantly different at $\mathrm{p}<0.05$.

\section{Oxidative stress markers}

The MDA level was significantly higher in $\mathrm{Cu}$ group compared to the control group, but it was significantly lower in the $\mathrm{CuF}$ and $\mathrm{CuL}$ groups compared to the $\mathrm{Cu}$ group (Table 2). The $\mathrm{CuF}$ group showed significantly higher levels than the control, while the CuL group was not significantly different from the control.

In contrast, the GSH and GPx levels were significantly lower in the $\mathrm{Cu}$ group compared to the control. These levels were significantly higher in the $\mathrm{CuF}$ and $\mathrm{CuL}$ groups compared to both the $\mathrm{Cu}$ groupand the control (Table 2). There were no differences in the MDA, GSH and GPx of the positive controls $\mathrm{F}$ and $\mathrm{L}$ and that of the control. 
Table 2. Mean testicular levels of MDA (nmol/g tissue), GSH (nmol/mg proteins), and GPx ( $\mu$ mol $\mathrm{GSH} / \mathrm{mg}$ proteins) of wistar rats treated with copper sulphate and C. monogyna leaves and fruits for one month. Results are expressed as mean \pm SD.

\begin{tabular}{llll} 
& MDA $(\mathbf{n m o l} / \mathbf{g}$ tissue $)$ & GSH $(\mathbf{n m o l} / \mathbf{m g}$ proteins $)$ & $\begin{array}{l}\text { GPx }(\boldsymbol{\mu m o l ~ G S H} / \mathbf{m g} \\
\text { proteins })\end{array}$ \\
\hline \multirow{2}{*}{ Control } & Testis & Testis & Testis \\
\cline { 2 - 4 } $\mathbf{C u}$ & $0.015 \pm 0.001^{\mathrm{c}}$ & $0.206 \pm 0.005^{\mathrm{ab}}$ & $0.067 \pm 0.007^{\mathrm{a}}$ \\
$\mathbf{F}$ & $0.018 \pm 0.002^{\mathrm{a}}$ & $0.066 \pm 0.001^{\mathrm{e}}$ & $0.026 \pm 0.002^{\mathrm{d}}$ \\
$\mathbf{L}$ & $0.015 \pm 0.005^{\mathrm{c}}$ & $0.209 \pm 0.001^{\mathrm{a}}$ & $0.071 \pm 0.001^{\mathrm{a}}$ \\
$\mathbf{C u F}$ & $0.015 \pm 0.002^{\mathrm{c}}$ & $0.203 \pm 0.001^{\mathrm{b}}$ & $0.070 \pm 0.009^{\mathrm{a}}$ \\
$\mathbf{C u L}$ & $0.016 \pm 0.002^{\mathrm{b}}$ & $0.110 \pm 0.001^{\mathrm{d}}$ & $0.057 \pm 0.008^{\mathrm{b}}$ \\
\hline
\end{tabular}

Means that do not share the same letter are significantly different at $\mathrm{p}<0.05$.

Results indicated a no difference in the absolute testicular weights of rats exposed to $\mathrm{Cu}$ for one month compared to the control group, which agrees with the finding of Chattopadhyay et al. [22]. Other researchers showed a slight decrease of rat testicular weight, in addition to a degenerative and necrotic effect of $\mathrm{Cu}$ on the seminiferous tubules and loss of spermatid from the center of the tubules [23]. In humans, $\mathrm{Cu}$ can produce adverse effects, including prostate enlargement, prostate infections, erectile dysfunction, depression, anxiety, testicular pain, and testicular cancer [1].

In this study, $\mathrm{Cu}$ was associated with lower testosterone concentration in rats; this result is in line with previous research showing that overdose of copper may affect the pituitary receptors, causing a reduction in the concentrations of $\mathrm{LH}$ and $\mathrm{FSH}$, the key hormones in controlling testosterone release [24]. As a copper an antagonist of zinc, high copper levels can reduce zinc concentration; notably, zinc plays an important role in the formation of androgens [25]. The accumulation of heavy metals in the testis may lead to the inhibition of steroidogenesis [26].

In this investigation, rats exposed to copper had poorer sperm motility, velocity (VCL, VSL, and VAP), lateral head displacement, beat cross frequency, and vitality. This suggest that accumulation of copper in the epididymis, prostate, and seminal vesicle may inhibit sperm motility, $\mathrm{BCF}$, and $\mathrm{ALH}$, possibly by affecting the spermatozoa energy source, and by modifying the sperm tail shape, which can explain the decrease of the velocity measures VCL, VSL, and VAP. Moreover, $\mathrm{Cu}$ ions may accumulate in sperm mitochondria due to attraction to sulfhydryl groups, causing less ATP production, which can reduce sperm motility [27,28]. A high copper level in the reproductive organs is probably responsible for lowering the $\mathrm{pH}$ of seminal plasma, which was reported to 
decrease sperm motility and the percentage of live sperm [13]. Other authors have found that a $\mathrm{pH}$ between 6.2 and 5.2 decreased sperm concentration, movement, and velocity measures VCL, VSL and VAP [29] by deregulating the $\mathrm{Na} / \mathrm{K}$ ATPase activity [30] that blocks the entrance of calcium, which is responsible for improving the amplitude of flagellar beat [13]. Moreover, as copper is an antagonist of zinc, the deficiency of the latter may lead to low sperm concentration. Compared to other cells, spermatozoa contain less cytoplasm. As the latter is where the antioxidants system is found, having less cytoplasm makes spermatozoa susceptible to oxidative stress through lipid peroxidation [31], which affects the acrosome reactivity reactivity, and increases DNA damage [32]. This may explain the increase in dead sperm observed in the copper treated-group.

In the Fenton reaction, the cupric ions $\mathrm{Cu}+2$ is reduced to cuprous $\mathrm{Cu}+$; the latter is able to catalyze the hydroxyl radical, which is highly reactive, and form lipid radicals from fatty acids [12]. In our study, the group treated with $\mathrm{Cu}$ showed higher MDA levels, suggesting that copper ions inhibited the antioxidant reactions [33]. Copper as a destructive metal to tissues can cause lipid peroxidation, which can increase the testicular MDA levels [34].

We expected that high levels of copper in different tissues could produce reactive oxygen species (ROS), DNA damage, and lipid peroxidation [35]. In the present study, the observed low levels of GSH and GPx in the Cu exposed rats were likely to be caused by ROS production [36], and by cellular usage of GSH and GPx in the metabolism and detoxification of copper [23]. In addition, GPx is involved in scavenging hydrogen peroxide and lipid peroxidase caused by copper ions [37].

Although the hawthorn has been reported to treat sexual weakness in Noth Africa $[38,39]$, there are not many studies about the effect of this plant on male fertility. The positive control of $\mathrm{L}$ showed higher sperm concentration and VCL in rats after a one-month treatment. As a powerful antioxidant, the fruits of hawthorn (Crataegus spp) may protect Sertoli cells from oxidative stress and may improve sperm quality due to the presence of phenolic compounds, oils, and vitamins. Previous findings showed the existence of vitamin $\mathrm{C}$ in the hawthorn and established the role of vitamin $\mathrm{C}$ on sperm characteristics [40], and the improvement of sperm concentration in male rabbits [41]. Similarly, our results showed an improvement in sperm quality in the $\mathrm{CuL}$ and $\mathrm{CuF}$ groups over the $\mathrm{Cu}$ group. The vitamin $\mathrm{C}$ in Crataegus spp. and in Rosaceae plants in general [40] helps in neutralizing hydroxyl, superoxide, and hydrogen peroxide radicals to prevent sperm agglutination [42]. In addition, vitamin $\mathrm{C}$ can both inhibit copper intestinal absorption, and increase its excretion [43]. The ability of vitamin $\mathrm{C}$ to scavenge free radicals could explain the remarkable lower levels of MDA observed in theCuL and $\mathrm{CuF}$ groups.

Furthermore, the augmentation in sperm motility in the CuL group is in line with the finding of Hu and Xiong [44] who observed that sperm from patients with asthenospermia showed increased 
motility when co-incubated with extracts from the genus hawthorn (Crataegus spp). Studies on the chemical composition of C. monogyna revealed the presence of vitamins, flavonoids, and oils $[40,45,46]$ that can act as a source of energy to boost sperm movement, increasing VSL and VAP [46]. This is probably why, in this study, the velocity measures (VCL, VSL, and VAP), ALH, and BCR were higher in the groups administered with C. monogyna extract.

Researchers previously found an effective role of C. monogyna extracts as an antioxidant [47,48] through the scavenging of free radicals and the inhibition of LDL oxidation [49]. Furthermore, the vitamin E in C. monogyna [45] can act as chain-breaking antioxidant [50], and prevents lipid peroxidation and tissue damage [42]. The occurrence of linoleic acid (omega-6); oleic acid (omega-9); oxalic acid bis (trimethylsilyl) ester; palmitic acid; and tetramethylcyclodecasiloxane that show powerful antioxidant activity [46] in C. monoyna might explain the lower levels of MDA and the higher levels of both GSH and GPx in the CuF and CuL groups. Previous results showed that omega-6 fatty acids can improve sperm motility [51], which may have contributed to the improvement of VCL, VSL, VAP, ALH and BCF levels in this study.

Quercetin was found in hawthorn, has been reported to act as a growth inhibitor for several malignant tumor cell lines, such as human epididymal cancer [52] by scavenging free radicals and chelating divalent cations [53]. Such a compound might have a role in reducing hydrogen peroxide, increasing sperm antioxidant defenses and preventing DNA damage induced by oxidative stress [54]. Moreover, quercetin may improve sperm quality by preserving the sex organs' functions [55]. Similarly, catechin polyphenols from C. monogyna, on the other side, were shown to reduce ROS by quenching free radicals and chelating transition metals [56], while catechins from green tea were shown to boost reproductive parameters [57]. This may explain the observed improvement of sperm concentration, motility, live sperm, velocity, ALH and BCF in the present study, especially in the CuL group.

In conclusion, copper induced oxidative stress, affecting testicular MDA, GSH, and GPx levels, and sperm quality parameters. The co-administration of extracts of C. monogyna fruits and leaves kept oxidative stress markers to almost their normal physiological ranges and improved semen quality, perhaps by mitigating the copper toxicity.

\section{ACKNOWLEDGEMENTS}

Authors would like to thank The General Directorate of Scientific Research and Technological Development (DGRSDT) for financial support (Award number 06/2016, recipient C. ABDENNOUR). Thanks are also given to Pasteur Institute (Algiers) for providing rats. 


\section{REFERENCES}

1. Badiye, A., Kapoor, N., Khajuria, H. (2013). Copper Toxicity: A Comprehensive Study. Research Journal of Recent Sciences, 2, 58-67.

2. Sinkovic, A., Strdin, A., Svensek F. (2008). Severe acute copper sulphate poisoning: a case report. ArhHig Rada Toksikol, 59(1), 31-5.

3. Blundell, S., Curtin, J., Fitzgerald, D. (2003). Blue lips, coma and haemolysis. Journal of Paediatrics and Child Health, 39(1), 67-8.

4. Mario, M. (2014). Abnormal Copper Homeostasis: Mechanisms and Roles in Neurodegeneration, Toxics, 2, 327-345.

5. Hagai, L., Niel, J., Anderson, M.A., Jaime, M., Dan, W.D., Irina, M., Rachel, P., Swan, H. (2017). Temporal trends in sperm counts: a systematic review and meta-regression analysis. Human Reproduction Updates, 23(6), 646-659.

6. Bamidele, R., Pelumi, O. (2017). Childlessness and Its Socio-Cultural Implication on Married Couples within Some Selected Yoruba Communities in South-West Nigeria. International Journal of Innovative Social Sciences \& Humanities Research, 5(1), 42-54.

7. Chen, L., Shi, G.R., Huang, D.D., Li, Y., Ma, C.C., Shia, M., Su, B.X., Shi, G.J. (2019). Male sexual dysfunction: A review of literature on its pathological mechanisms, potential risk factors, and herbal drug intervention. Biomedicine and Pharmacotherapy, 112, 108-585.

8. Duruibe, J., Ogwuegbu, M.O.C., Egwurugwu, J. (2007). Heavy Metal Pollution and Human Biotoxic Effects. International Journal of Physical Sciences, 2(5), 112-118.

9. Swan, H.S., Elkin, E.P., Fenster, L. (2000). The question of declining sperm density revisited: an analysis of 101 studies published 1934-1996. Environmental Health Perspectives, 108(10), 961-966.

10. Liu, J.Y., Yang, X.F., Sun, X., Zhuang, C., Xu, F., Li, Y. (2016). Suppressive Effects of Copper Sulfate Accumulation on the Spermatogenesis of Rats. Biological Trace Element Research, 174, 356-361.

11. Wong, W.Y., Flik, G., Groenen, P.M.W., Swinkels, D.W., Thomas, C.M.G., CopiusPeereboom, J.H.J., Merkus, H.M.W.M., Steegers-Theunissen, R.P.M. (2001). The impact of calcium, magnesium, zinc, and copper in blood and seminal plasma on semen parameters in men. Reproductive Toxicology, 15, 131-136. 
12. Moriwaki, H., Osborne, M.R., Phillips, D.H. (2008). Effect of mixing metal ions on oxidative DNA damage mediated by a Fentom-type reduction. Toxicology in Vitro, 22(1), 36-44.

13. Eidi, M., Eidi, A., Pouyan, O., Shahmohammadi, P., Fazaeli, R., Bahar, M. (2011). Seminal plasma levels of copper and its relationship with seminal parameters. Iranian Journal of Reproductive Medicine, 8(2), 60-65.

14. JibrinBala, Y., Meriçli, A.H. (2016). Pharmacological activities of Crataegus species: A review. International Journal of Multidisciplinary Research and Development, 3, 73-76.

15. Fong, H.H., Bauman, J.L. (2002). Hawthorn. Journal of Cardiovascular Nursing, 16, 1-8.

16. Rice-Evans, C. (2004). Flavonoids and isoflavones: absorption, metabolism, and bioactivity. Free Radical Biology and Medicine, 36(7), 827-8.

17. Jeyendran, R.S., Vander-Van, H.H., Perez-Peleaz, M., Crabo, B.G., Zanevld, L.J.D. (1984). Development of an assay to assess the functional integrity of the human sperm membrane and its relationship to other semen characters. Journal of Reproducion and Fertility, 70(1), 219228.

18. Weckbercker, G., Cory, J.G. (1988). Ribonucleotide reductase activity and growth of glutathione depended mouse leukaemia L 1210 cells in vitro. Cancer Letters, 40, 257-264.

19. Bradford, M.M. (1976). Rapid and Sensitive Method for the Quantitation of Microgram Quantities of Protein Utilizing the Principle of Protein-Dye Binding. Analytical Biochemistry, 72, 248-254.

20. Ohkawa, H., Ohishi, N., Yagi, K. (1979). Assay for lipid peroxidation in animal tissues by thiobarbituric acid reaction. Analytical Biochemistry, 95, 351-358.

21. Flohe, L., Gunzler, W.A. (1984). Analysis of glutathione peroxidase. Methods of Enzymology, $105,114-121$.

22. Chattopadhyay, A., Sarkar, M., Biswas, N.M. (2005). Dose-dependent effect of copper chloride on male reproductive function in immature rats. Kathmandu University Medical Journal, 3(4), 392-400.

23. Mandil, R., Rahal, A., Parkash, A., Gangwar, S.K. (2016). Ameliorative potential of atocophenol against flubendiamide and copper-induced testicular-insult in wistar rats. Chemico-bioloical Interactions, 260, 91-101. 
24. Chang, CS., Choi, J.B., Kim, H.J., Park, S.B. (2011). Correlation between serum testosterone level and concentration of copper and zink in hair tissue. Bioloical Trace Element Research, 144(1-3), 264-271.

25. Bedwal, R.S., Bahuguna, A. (1994). Zinc, copper and selenium in reproduction. Experientia, 50(7), 626-40.

26. Wiebe, J.P., Salhanick, A.I., Myer, K.I. (1983). On the mechanism of action of lead in the testis: in vitro suppression of FSH receptors, cyclic AMP and steroidogenesis. Life Science, 32(17), 1997-2005.

27. Krumschnabel, G., Manzal, C., Berger, C., Hofer, B. (2005). Oxidative stress, mitochondiral permeability transition, and cell death in $\mathrm{Cu}$-exposed trout hepatocytes. Toxical Toxicology and Applied Pharmacology, 209(1), 62-73.

28. Knazicka, Z., Tvrda, E., Bardos, L., Lukac, N. (2012). Dose- and time- dependent effect of copper ions on the viability of bull spermatozoa in different media. Journal of Environmental Science and Health Part A Toxic/Hazardous Substances and Environmental Engineering, 47(9), 1294-300.

29. Zhou, J., Chen, L., Li, J., Li, H., Hong, Z., Xie, M., Chen, S., Yao, B. (2015). The Semen pH Affects Sperm Motility and Capacitation. PLoS ONE, 10(7), e0132974.

30. Jimenez, T., Sanchez, G., Wertheimer, E.V., Blanco, G. (2010). Activity of the Na,K-ATPase alpha4 isoform is impor- tant for membrane potential, intracellular $\mathrm{Ca} 2+$, and $\mathrm{pH}$ to maintain motility in rat spermatozoa. Reproduction, 139(5), 835-45.

31. Olivari, F.A., Hernảndez, P.P., Allende, M.L. (2008). Acute copper exposure induces oxidative stress and cell death in lateral line hair cells of zebrafish larvea. Brain Research, 1244, 1-12.

32. Sadek, A.S., Abd El Shakour, A., Zaki A., Ibrahim, A.M., Mahmoud, I.S., Mostafa, T.B., (2011). Sperm chromatin condensation in infertile men with varicocele before and after surgical repair. Fertility and Sterility, 95(5), 1705-8.

33. Dupont, C.L., Grass, G., Rensing, C. (2011). Copper toxicity and the origin of bacterial resistance-new insights and applications. Metallomics, 3(11), 1109-1118.

34. Witting, P.K., Bowry, V.W., Stocker, R. (1995). Inverse deuterium kinetic isotope effect for peroxidation in human low-density lipoprotein (LDL): a simple test for tocopherol- mediated peroxidation of LDL lipids. FEBS Letters, 375(1-2), 45-49. 
35. Sevcikova, M., Modra, H., Slaninova, A., Svobodova, Z. (2011). Metals as a cause of oxidative stress in fish: a review. Veterinárnímedicina, 56(11), 537-546.

36. Jiang, W.D., Liu, Y., Kai, H., Jiang, J., Li, S.H., Feng, L., Zhou, X.Q. (2014). Copper exposure induces oxidative injury, disturbs the antioxidant system and changes the Nrf/ARE (CuZnSOD) signaling in the fish brain: protective effect of myo-inositol. Aquatic Toxicology, 155C, 301313.

37. Danyelle, T.M., Kanneth, T.D. (2003). The role of glutathion S-transferase in anti-cancer drug resistance. Oncogene, 22(47), 7369-75.

38. Miller, A.L. (1998). Botanical influences on cardiovascular disease. Alternative Medicine Review, 3, 422-431.

39. Ju, L.Y. (2005). Crataegusoxyacantha (aubepine) in the use as herb medicine in France. ZhongguoZhong Yao ZaZhi, 30(8), 634-40.

40. Rosario, G.M., Emmanuel, I.E., Raúl, N.A. (2013). Antioxidant compounds in hawthorn fruits (Crataegus spp.) of Mexico. Revista Mexicana de Biodiversidad, 84(4), 1298-1304.

41. Yousef, M.I., Abdullah, G.A., Kamel, I. (2003). Effect of ascorbic acid and vitamin E supplementation on semen quality and biochemical parameters of male rabbits. Animal Reproduction Science, 76(1-2), 99-111.

42. Agarwal, A., Nallella, K.P., Allamaneni, S.S. (2004). Said TM. Role of antioxidants in treatment of male infertility: an overview of the literature. Reproductive Biomedicine Online, $8(6), 616-27$.

43. Frieden, E. (1986). Perspectives on copper biochemistry. Clinical Physiology and Biochemistry, 4(1), 11-9.

44. Hu, L., Xiong, C.L. (2006). The influence of medicated serum with root of Crataeguscuneata on human sperm motility parameters in vitro. ZhongguoZhong Yao ZaZhi. 31(4), 333-5.

45. Keser, S., Celik, S., Turkoglu, S., Yilmaa, Ö.,Turkoglu, I. (2015). Vitamin, Sterol and Fatty Acid Contents of Some Edible and Medicinal Plants from East and Southeast Anatolia (Turkey). Turkish Journal of Pharmaceutical Sciences, 12(2), 46-59.

46. Bechkri, S., Berrehal, D., Semra, Z., Bachari, K., Kabouche, A., Kabouche, Z. (2017). Composition and biological activities of seeds oils of two Crataegus species growing in Algeria. . Journal of Materials and Environmental Sciences, 8(3), 1023-1028. 
47. Froehlicher, T., Hennebelle, T., Martin-Nizard, F., Cleenewerck, P., Hilbert, J.L., Trotin, F., Grec, S. (2009). Phenolic profiles and antioxidative effect of hawthorn cell suspension, fresh fruits, and medicinal dried parts. Food Chemistry, 115(3), 897-903.

48. Masteikova, R., Muselik, J., Bernatonienè, J., Bernatonienè, R. (2007). Antioxidative activity of Ginkgo, Echinacea, and Ginseng tinctures. Medicina (Kaunas), 43(4), 306-9.

49. Liu, T., Cao, Y., Zhao, M. (2010). Extraction optimization, purification and antioxidant activity of procyanidins from hawthorn (C. pinnatifidaBge. var. major) fruits. Food Chemistry, 119(4), 1656-1662.

50. Hwang, K. and Dolores J.b. (2013). Molecular mechanisms of antioxidants in male infertility. In: S.J. Parekattil and A. Agarwal (eds.), Antioxidants in male infertility: A guide for clinicians and researchers, (pp 93). New York Heidelberg Dordrecht London: springer.

51. Putri, N.D., Lipoeto, N.I., Reza, M. (2018). Effects of Omega 3 on Testosterone Hormone Levels and Quality of Spermatozoa in Obese RattusNorvegicusWistar Albino Strai. International Biological and Biomedical Journal Summer, 4(3), 156-163.

52. Kanadaswami, C., Lee, L.T., Lee, P.P.H., Hwang, J.J., Ke, F.C., Huang, Y.T., Lee, M.T. (2005). The antitumor activities of flavonoids. In vivo, 19(5), 895-909.

53. Seddiki, Y., Helena, M., Fernando, M. (2017). Antioxidant Properties of Polyphenols and Their Potential Use in Improvement of Male Fertility: A Review. Biomedical Journal of Scientific and Technical Research, 1(3), 2574-1241.

54. Zribi, N., Chakroun, FN., Ben Abdallah, F., Elleuch, H., Sellami, A., Jalel, G., Rebai, T., Fakhfakh, F., Ammar-Keskes, L. (2012). Effect of freezing-thawing process and quercetin on human sperm survival and DNA integrity. Cryobiology, 65(3), 326-331.

55. Taepongsorat, L., Tangpraprutgul, P., Noppadon, K., Malaivijitnond, S. (2008). Stimulating effects of quercetin on sperm quality and reproductive organs in adult male rats, Asian Journal of Androloy, 10(2), 249-258.

56. Nabavi, S.F., Habtemariam, S., Touqeer, A., Antoni, S., Daglia, M., Eduardo, S., Nabavi, S.M. (2015). Polyphenolic Composition of Crataegusmonogyna Jacq: From Chemistry to Medical Applications. Nutrients, 7, 7708-7728.

57. Sajid, U., Yingying, H., Lei, Z., Shibin, F., Ibrar, M.K., Jinjie, W., Yu, L., Xichun, W. (2018). Therapeutic Role of Green Tea Polyphenols in Improving Fertility: A Review. Nutrients, 10(7), 834. 